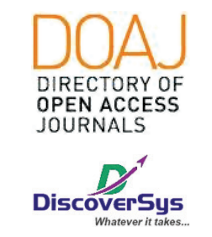

Published by DiscoverSys

\section{Encapsulated liposome toward anthocyanin in Pectin-Based Dry Jelly as a breakthrough therapeutic management in pediatric obesity: a literature review}

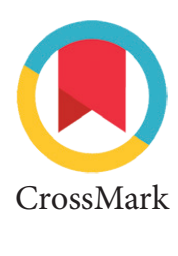

\author{
Putu Nandika Tungga Yudanti Mahardani, ${ }^{1 *}$ Komang Diah Kurnia Kesumaputri, ${ }^{1}$ \\ I Gede Wikania Wira Wiguna, ${ }^{1}$ Dyah Kanya Wati ${ }^{2}$
}

\section{ABSTRACT}

Results: ASN in the purple sweet potato has anti-obesity effect by decreasing the a-glucosidase enzyme and a-amylase, increasing glucagon-like-peptide- 1 and peptide YY, changing the size of adipose cell, decreasing the lipogenic activity and inflammation, increasing the lipolysis and $\beta$-oxyanion adipose cell, as well as increasing the concentrate of brain-derived neutrophil factor in a brain. To increase the bioavailability of ASN, it has to be done the encapsulation with liposome base. Modality is packaged in the dry jelly form with pectin base as a formulation in powder form taken orally. The modality consumption is 24 $\mathrm{mg} / \mathrm{kg}$ of weight, however, after eating, the obese people tend to give the weight decreasing effect and cross section attractive to target modalities. Conclusion: According to the studies, the ASN from purple sweet potato and package in Pectin-Based Dry Jelly could be used as a novel strategy in managing the pediatric obesity.

Keywords: Anthocyanin, dry jelly, pectin, pediatric obesity, purple sweet potato.

Cite This Article: Mahardani, P.N.T.Y., Kesumaputri, K.D.K., Wiguna, I.G.W.W., Wati, D.K. 2020. Encapsulated liposome toward anthocyanin in Pectin-Based Dry Jelly as a breakthrough therapeutic management in pediatric obesity: a literature review. Intisari Sains Medis 11(1): 153-159. D0I: 10.15562/ism.v11i1.524

'Undergraduate Student, Faculty of Medicine, Udayana University, Bali, Indonesia

${ }^{2}$ Department of Pediatrics, Faculty of Medicine, Sanglah General Hospital, Bali, Indonesia
${ }^{*}$ Correspondence to: Putu Nandika Tungga Yudanti Mahardani; Undergraduate Student, Faculty of Medicine, Udayana University, Bali, Indonesia; ptnndk@gmail.com

Diterima : 14-06-2019 Disetujui: 29-01-2020 Diterbitkan: 30-01-2020

\section{INTRODUCTION}

Pediatric obesity is the highest prevalence metabolic disease in the children and adolescent. ${ }^{1}$ According to the national survey conducted by The Primary Health Research on 2013, the prevalence of Indonesia's children who are obesity is $11,9 \%$ and it is getting increased. ${ }^{2}$ The similar case is also happened in another country on 1980 with the estimation number of obese people is 170 billion over the world on 2012. ${ }^{1,3,4}$ This increasing is reported about $18 \%$ in 2010 is the age group of 6-11 years old and 5\%-18\% is the age group of $12-19$ years old within the same interval. ${ }^{1}$ This count is still based on Body Mass Index (BMI) even though the latest progress showed that the measurement of waist circumference is a more precise method of determining obesity. ${ }^{1,5}$

The children who got obesity tend to five times higher than normal children who suffer obesity while being adults. ${ }^{6}$ It is dangerous because of many complications within obesity such as cardiovascular disease, diabetes mellitus type 2, hypertense, endothelium disfunction, and several types of cancer such as colorectal cancer. ${ }^{1,4,7}$ Besides that, as the one of noncommunicable diseases types (NCD), obesity in the children can cause psychological disorder that will also affect the children's growth later. ${ }^{1,4}$

The strategy for handling obesity is still spinning on the program implementation that introduces the life-style changes of children. Global Strategy on Diet, Physical Activity and Health (DPAS) is a program aimed to overcome the obesity risk factors such as lack of physical activity and unhealthy diet. ${ }^{4}$ There is health school in Indonesia aimed to give motivation in doing healthy life-style on children. ${ }^{8}$ The purpose of the progam is difficult to be achieved because it is for long-term effect and depending on the motivation and the life-style of obesity people. ${ }^{9}$

Furthermore, pediatric obesity management is different form adult obesity management which 
generally involves sibutramine and orlistat at BMI level of $\geq 30 \mathrm{~kg} / \mathrm{m}^{2}{ }^{1,7}$ Orlistat is categorized as dangerous because it has a side effect such as tachycardia, increasing the blood pressure, and insomnia. ${ }^{7}$ Nowadays, orlistat is the one and only medicine that is allowed by Food and Drug Administration (FDA) for managing obesity on the patients who are $\geq 12$ years old with obesity conditions that are classified as severe. ${ }^{10}$ Bariatric surgery on the children about $\geq 13$ years old will also be considered after BMI of $\geq 35 \mathrm{~kg} / \mathrm{m}^{2}$ because of the serious complication risk which is death after surgery, intestinal obstruction, gastrointestinal (GI) bleeding, infection, and chronic nutritional deficiency. ${ }^{1,10}$ Another problem on managing pediatric obesity is a modality target which is children who have difficulty in taking medication. ${ }^{11}$

The lack of effectivity in pediatric obesity management is lifting the potential utilization of natural ingredients as a medicine that has minimal side effects and is relatively safer for obese people. One of natural ingredients which significantly develops nowadays is anthocyanin (ASN). ${ }^{12}$ The abundant ASN source in Indonesia is purple sweet potato (Ipomea batatas L.)..$^{13}$ The high sweet potato production in Indonesia which amounted to 2.262.124 tons in 2016, strongly supports the implementation of obesity therapy by using purple sweet potato in Indonesia. ${ }^{14}$ Therapy model such ASN consumption in the purple sweet potato has anti-obesity effect by increasing $\alpha$-glucosidase $(\alpha \mathrm{G})$ and $\alpha$-amylase $(\alpha \mathrm{A})$ enzyme, increasing glucagon-like-peptide-1 (GLP-1), and peptide YY (PYY) in the GI system. ${ }^{15,16}$ Anti-obesity effect is also shown through the changes in the size of adipose cells, decreased lipogenic activity and inflammation as well as increased lipolysis and $\beta$-oxidation in adipose cells. ${ }^{17}$ The purple sweet potato also increases the concentration of brain derived neutrophil factor (BDNF) as hunger inhibiting agent in hypothalamic obesity. ${ }^{18,19}$

One of the obstacles that limits the use of ASN as an anti-obesity medicine is its low bioavailability in the body. ${ }^{12}$ The processing of purple sweet potato which used encapsulation method with liposomes can protect the active ingredients contained therein. ${ }^{20}$ The encapsulated ASN can be integrated with the modality model in the form of pectinbased dry jelly as a gel-base. The main concept of dry jelly is a formulation in the form of solid powder that does not contain water when stored and will turn into jelly after adding water at the time it will be consumed. ${ }^{21}$ The component of dry jelly which contains pectin, dibasic calcium phosphate hydrate $(\mathrm{DCPH})$, gluconic- $\delta$-lactose (GDL), sucrose, and water can create an environment with a low $\mathrm{pH}$ and do not involve the high temperature, thus it is safe to be formulated with the active ingredients in other medicines, such as ASN..$^{21,22}$ These characteristics are not found in conventional oral jelly manufacturing. ${ }^{21}$

This literature review purposes to examine the ASN potential in purple sweet potato as pediatric obesity management which is processed by encapsulation method that used liposome on the dry jelly. This method gives a big chance to the development modality of ASN which is not only without a side effect and its high bioavailability, but also with the model that is known well in the children as a modality target. Besides that, ASN on purple sweet potato is able to produce natural dyes that provide high selling value and reduce the use of synthetic food coloring which has hyperactive disorders side effect in children. ${ }^{13,23}$

\section{Literature Search Strategy}

Literature search was conducted on January, $14^{\text {th }}-$ February, $2^{\text {nd }} 2019$ in 3 online-based scientific databases, namely Google Scholar, PubMed, and Research Gate. The key words used were "pectinbased dry jelly", "anthocyanin", and "pediatric obesity". The inclusion criteria used in this literature review are in vivo studies, however, the exclusion criteria used are in vitro studies. After conducting a literature study, the next step is screening, so that it was obtained 73 apropriate journals, those are 4 from Google Scholar, 65 from PubMed, and 4 from Research Gate. All journals obtained are further critically examined in terms of validity, importance, and applicability. The types of data obtained are varied, but mostly are qualitative. All of data were synthesis using narrative sentences in systematic and logic

\section{Pediatric Obesity Pathogenesis}

Obesity pathogenesis in the GI system happened through a decrease in the secretion of GLP-1 and PYY by L-cell as well as $\alpha \mathrm{G}$ and $\alpha \mathrm{A}$ in the small intestine. ${ }^{24-28}$ GLP-1 works by increasing insulin section, PYY as satiety inducer, while $\alpha A$ and $\alpha G$ act as an enzyme for glucose absorption in the body. ${ }^{29-31}$

Pediatric obesity is also occurred because of the defunction of adipose system such as hypertrophy and inflammation. ${ }^{32}$ Hypertrophy of adipose cells causes the increasing free fatty acid (FFA) product and trigger the inflammation which is shown by monocyte chemotactic protein-1 (MCP-1) secretion, haptoglobin, cyclooxigenase-2 (COX-2), and interleukin-6 (IL-6). ${ }^{33-36}$ The disfunction of adipose system is also characterized by fat metabolism disorder on lipogenesis, lipolysis, and $\beta$-oxidation which involves lipoprotein lipase (LPL), hormone sensitive lipase (HSL), perilipin, acyl co-A dehydrogenase 
(ACD), and acyl co-A oxidase (ACO). ${ }^{37,38}$ Besides that, there was a decrease in sterol binding element regulatory protein 1-c (SREBP-1c) as a transcription factor for fatty acid synthetase (FAS), and acetyl co-A (ACS) which was also involved in the process. ${ }^{39}$

Hypothalamic obesity in the children happened because there was lesion on ventromedial hypothalamus (VMH) which resulted in impaired FFA mobilization. ${ }^{40}$ Not only containing sensitive neurons towards glucose and stimuli that induce hunger, but $\mathrm{VMH}$ also responds to the melanocortin activation with 3 and 4 receptors (MC3R/ MC4R) through $a$-melanocyte stimulating hormone $(a-\mathrm{MSH})$ in the paraventricular nucleus $(\mathrm{PVN})$, which regulates the inhabitation of hunger through BDNF induction (Figure 1). ${ }^{41,42}$

\section{Construction Mechanism}

Modality in the form of ASN is processed by extraction method such as Microwave Assisted Extraction (MEC), then it is encapsulated by liposome and used Supercritical Carbon dioxide (SC-CO2) method, after that it is mixed with pectin-based dry jelly. Extraction method with MEC produces the highest ASN level compared to the maceration method or others. As an encapsulation material, liposomes are suitable for medicine distribution that are hydrophilic, hydrophobic, and amphipathic so that they are not easily degraded, especially after mixing with water during the process of making dry jelly. SC-CO2 method was

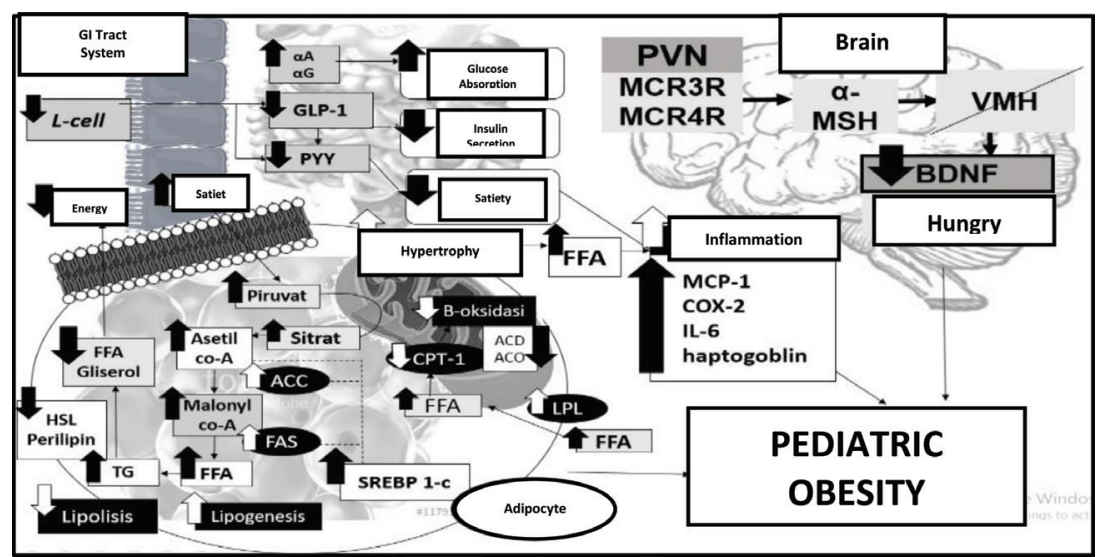

Figure 1 Pediatric obesity pathogenesis (Notes: FFA: free fatty acid, TG: triacylglycerol, aA: $\alpha$-amylase, aG: $\alpha$-glucosidase, GLP-1: glucagon-like-peptide-1, PYY: peptide YY, MCP-1: monocyte chemotactic protein-1 COX-2: cyclooxigenase-2, IL-6: interleukin-6, LPL: lipoprotein lipase, HSL: hormone sensitive lipase, ACD: acyl co-A dehydrogenase, ACO: acyl co-A oxidase, SREBP 1-c: sterol regulatory element binding protein 1-c, FAS: fatty acid synthetase, ACS: acetyl co-A. VMH: ventromedial hypothalamus, MC3R/MC4R: melanocortin receptor 3 dan 4, a-MSH: a-melanocyte stimulating hormone, PVN: paraventricular nucleus, BDNF: brain-derived neurotrophic factor) chosen because it has several advantages, including can be carried out at low temperature, has high diffusivity, voltage, and low viscosity and produces relatively smaller particle sizes, thus it is effectively used for bioactive encapsulation that is labile at high temperature, which is like ASN if it is compared to spray drying, thin film hydration, or similar methods. ${ }^{45,47}$ Besides that, dry jelly is chosen because the storage formulation is in powder form and does not require high temperature in its processing. ${ }^{21}$

The ingredients needed are purple sweet potato, ethanol (96\%), and tartaric acid, soy lecithin, high density lipoprotein (HDL) cholesterol, citric acid monohydrate (99\%), and CO2 solution (purity $99.99 \%)^{21,43,45}$ Some literature showed that soy lecithin can reduce low density lipoprotein (LDL) cholesterol, reduce obesity, and lipid metabolism, thus it is well used as an encapsulation material for anti-obesity modalities. ${ }^{48,49}$ The use of liposomes with similar materials has been used as a coating agent for anti-obesity modalities in other studies. ${ }^{50,51}$

\section{Raw suspension extraction and formulation}

Purple sweet potatoes should be cleaned, peeled, and rinsed to be sliced into thin slices $(1.5 \mathrm{~mm})$ with a slicer. The samples were steamed for five minutes at $95^{\circ} \mathrm{C}$ with steamer then dried at $60^{\circ} \mathrm{C}$ for eight hours using a dryer. After drying, the samples were milled with a grinder and sifted using 80 mesh sieves. ${ }^{43}$

About 20 grams of purple sweet potato flour was put into Erlenmeyer and added with $0.75 \%$ ethanol-tartaric acid solvent with a material and solvent ratio: 1:20. Erlenmeyer is placed on a magnetic stirrer for 15 minutes and then put into a microwave set at 80 watts for 300 seconds. The samples were left cold at room temperature to be centrifuged at $4000 \mathrm{rpm}$ for 10 minutes at $25^{\circ} \mathrm{C}$. Supernatant obtained is passed through filter paper and produces a deposit-free ASN filtrate. Furthermore, the filtrate was concentrated with a rotary evaporator at $40^{\circ} \mathrm{C}$, and the pressure of $200 \mathrm{mBar}$. The extract was stored in a dark bottle and sealed, then stored in the refrigerator at $0^{\circ} \mathrm{C}$. The extraction process that used this method resulted $687.58 \pm 6.08 \mathrm{ppm}$ ASN and phenolic acid of $5186.51 \pm 167.29 \mathrm{ppm}^{43}$

The next step is formulated extract ASN into mixture-suspension which was used as encapsulation material. ASN with $10 \%$ concentration $(2.5 \mathrm{mM})$ is dissolved in $100 \mathrm{~mL}$ citric acid buffer solution ( $\mathrm{pH}$ 3.5) in a dark condition. Then, soy lecithin is added into ASN mixing while still steered for 30 minutes using magnetic stirrer at $1200 \mathrm{rpm}$. The final phospholipid concentration is set at $20 \mathrm{mM}$. After that, $20 \%(5 \mathrm{mM})$ of HDL cholesterol was 


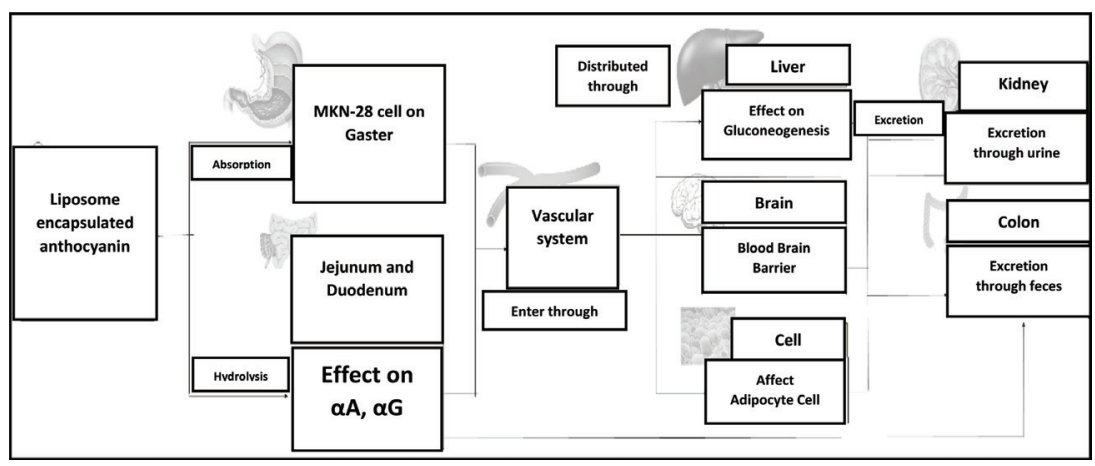

Figure 2 Pharmacokinetic Anthocyanin of Purple Sweet Potato Which Encapsulated Liposomes

added slowly and mixed evenly with ASN suspension in a rotation speed that is about $1200 \mathrm{rpm}$ using a similar stirrer. Then, the suspension of the mixture formed is stored in a dark room at $40^{\circ} \mathrm{C}$ for \pm 1 week. ${ }^{45}$

\section{Liposome encapsulation with SC- $\mathrm{CO}_{2}$ method}

$\mathrm{SC}-\mathrm{CO} 2$ is an encapsulation method which used $\mathrm{CO} 2$ as a solvent. At the first experiment, $6 \mathrm{~mL}$ crude suspension mixture was closed in $10 \mathrm{~mL}$ of high-pressure cells. In addition, $\mathrm{CO}_{2}$ was added to the cell to release the air contained in it. Before reaching a temperature of $50^{\circ} \mathrm{C}$, the cell remained in a balanced state. Magnetic stirrer was used in mixing all cell components with a rotational speed of $550 \mathrm{rpm}$ for an hour. In the phase of $\mathrm{CO}_{2}$ dispersion in the mixed solution, the air pressure was lowered under constant conditions. The crude suspension was used to make liposome at a pressure of $3000 \mathrm{bar}$, the pressure drop speed is $90 \mathrm{bar} /$ minute, and at a temperature of $50^{\circ} \mathrm{C} .{ }^{45}$

As a final result, that was formed encapsulated ASN which has particle size about $159 \pm 5 \mathrm{~nm}$. Encapsulation Effectivity (EE) and Bioactive Loading (BL) ASN with this method is reported that they reached $50.6 \%$ and $15 \%$ as well as potential zeta of $-40.2 \mathrm{mV}^{45}$

\section{Dry jelly production}

Encapsulated ASN and all basic ingredients, except water, to form dry jelly was placed in polyethylene plastic and stirred until evenly mixed. Then, it must be added water in regard to make the ration of dry jelly and water was $1: 3$, stirred for \pm 30 seconds and left to harden (freeze). The recommended formulation was pectin (Degree of Methylation/DM: $39,8 \%)$ of $1,5 \%, \mathrm{DCPH}$ and $2 \%$ GDL, sucrose of $19,5 \%$, and water of $75 \%$. GDL will be hydrolyzed to gluconate in addition of water, creating an acidic atmosphere that makes DCPH release $\mathrm{Ca} 2+$ when the pectin dissolves, while sucrose prevents clots from forming the dry jelly. The method of medicine formulation in the form of dry jelly has been done for acetaminophen in previous studies, that was without causing significant changes in jelly structure or dissolution characteristics of the medicine. ${ }^{21}$

\section{Administration}

Dry jelly was administered orally after meals. It was because one of ASN effects that works such as acarbose, a medicine with an antihyperglycemic effect that works through inhibition of the enzymes $\alpha \mathrm{A}$ and $\alpha \mathrm{G}$. Oral administration is the most appropriate and beneficial administration because it is non-invasive and provides comfort to patients. ${ }^{52}$ Although the oral route has a weakness, which must pass the first pass effect, this can be solved by the encapsulation of ASN with liposomes. Encapsulation was able to increase the half-life of a modality three times from a non-encapsulated ASN. A good half-life was obtained when dry jelly was stored at $4^{\circ} \mathrm{C} .5^{53}$ Dry jelly potential dose which was given in the obesity management of the children was $24 \mathrm{mg} / \mathrm{kg} .{ }^{54}$

\section{Pharmacokinetics}

Drug released ASN from liposomes reached $35-40 \%$ for the first eight hours and decreased by $5-10 \%$ in the next 24 hours. ${ }^{55}$ ASN was slowly released from liposomes in the stomach. ${ }^{45}$ The concentration of ASN that can be seen quickly in plasma showed that ASN absorption can occur through the gastric mucosa and $\mathrm{MKN}-28$ cells. ${ }^{56}$ Liposomes were degraded faster in the small intestine with an ASN absorption distribution of 55.3 $7.6 \%$ in jejunal tissue and $10.4 \pm 7.6 \%$ in duodenal tissue. ${ }^{57} \mathrm{ASN}$ was reported to reach the bloodstream within 6-20 minutes and reached maximum levels in the body after 15-60 minutes after consumption. ${ }^{58}$ ASN absorption can be done through the hydrolysis conversion process of ASN into aglycone which required the role of the enzyme-glucosidase, glucuronidase and $\alpha$-rhamnoses or directly using Sodium Glucose Transporter-1 (SGLT-1). ${ }^{58-60}$

Absorption of ASN cations or cyanidin-3-glycoside (cy-3-glc), occurred by a transportation process which is facilitated by the Bili translocase enzyme and can enter the cell in just 60 seconds after consumption. ${ }^{61}$ Other vivo studies in male rats undergoing the ASN diet program showed that about $51.5 \%$ of the amount of ASN was entered the body of mice which is accumulated in the liver. ${ }^{62,63}$ Other organ that was important target for ASN distribution was brain, where ASN has the ability to pass through the blood brain barrier. ${ }^{64,65}$ In addition, the kidney was also the target of the ASN distribution, which was then excreted through urine. ${ }^{66}$ ASN has low permeability, so ASN that cannot be absorbed will be excreted through feces (Figure 2). ${ }^{67}$ 


\section{Pharmacodynamic}

According to Esatbeyoglu et al, purple sweet potato can inhibit the secretion of $\alpha G$ and $\alpha A$ enzymes in the intestine. ${ }^{15}$ The inhibition ability of the aG enzyme was related to the content of cy-3-glc, which was a type of ASN that was found in purple sweet potatoes. ${ }^{16}$ Kato et al. also observed that an increase in the secretion of GLP-1 followed by PYY and ASN in the GI system. ${ }^{68,69} \mathrm{Ju}$ et al observed a decrease in gluconeogenesis in the liver by cyanidin 3-caffeoyl-p-hydroxybenzoyksophoroside-5-glucoside (PEAK9), one component of ASN in purple sweet potato. ${ }^{70}$

The effect of purple sweet potato on adipose cells was shown by Ju Jae Hyun et al. Purple sweet potatoes can reduce the size of adipose cells in mice, which was also shown by a decrease in triacylglycerol (TG) followed by a decrease in leptin secretion..$^{17,71}$ In addition, there was a decrease in lipogenic activity by adipose cells characterized and decreased expression of ACS, FAS, LPL, and SREBP-1 c. Purple sweet potatoes can also increase lipolysis activity which was indicated by increased HSL and perilipin expression. Increased activity of $\beta$-oxidation FFA was demonstrated through the increased expression of ACO, CPT, and ACD in $\beta$-oxidation FFA activity. The $\beta$-oxidation activity of the FFA that took place in the adipose cell mitochondria can provide energy for the body. There was also a decrease in inflammatory factors in adipose cells such as COX-2, IL-6, haptoglobin, and MCP- $1 .{ }^{17}$

According to Zhuang et al's study, ASN contained in purple sweet potato can improve BDNF concentrations in hippocampus in mice treated with HFD. ${ }^{19}$ This occurred because of the characteristics of the ASN that can cross the bloodbrain barrier. ${ }^{58,72}$ Zhuang et al. also observed that ASN contained in purple sweet potatoes was able to improve the condition of obesity, glucose tolerance, and insulin resistance in HFD-induced mice. ${ }^{19}$ This is likely due to the ability of ASN to increase BDNF concentration which can inhibit hunger. This activity showed an improvement in the hypothalamic obesity which was caused by a decrease in BDNF and $\mathrm{VMH}$ lesions as well as inability to continue hunger inhibition activities initiated by binding of a-MSH to MCR3 / MCR4 in PVN. The same results were also obtained by Maekawa et al through injection of BDNF intracerebroventricular. ${ }^{73}$

\section{Clinical effect}

According to Esatbeyoglu et al, the half-life of the inhibition of the $\alpha \mathrm{A}$ enzyme was achieved when the concentration of ASN extract was $7.22 \mathrm{~g} / \mathrm{L}$, whereas the half-life of the aG enzyme inhibition achieved when the concentration was $5.99 \mathrm{~g} / \mathrm{L}$ with effects that could rival acarbose, medicine with similar mechanisms. ${ }^{16}$ Kato et al. also observed an increase in the greatest GLP-1 secretion in the administration of ASN of $1000 \mu \mathrm{g} / \mathrm{ml}^{68}$

According to Ju Jae Hyun et al., if this is compared to controls, there was a $92.6 \%$ decrease in TG accumulation and $62.4 \%$ decrease in leptin secretion in the treatment of $3000 \mu \mathrm{g} / \mathrm{ml}$ extract, indicating the ability of ASN in purple sweet potatoes to reduce the size of adipose cells. ${ }^{17}$ Purple sweet potato can reduce lipogenic activity by suppressing ACS expression up to $34.8 \%$, FAS up to $11.3 \%$, and LPL by $52.9 \%$, and SREBP- $1 \mathrm{c}$ up to $16.7 \%$ in treatment of $3000 \mu \mathrm{g} / \mathrm{ml}$ compared to controls. The effect of purple sweet potato that was inducing lipolytic factors can be seen by increasing HSL to $129.7 \%$ and perilipin up to $144.2 \%$ in the treatment of $3000 \mu \mathrm{g} / \mathrm{ml}$. Changing the expression factor related to $\beta$-oxidation can be seen through an increase in ACO expression up to $176 \%$, CPT-1 to $194 \%$, and ACD up to $193 \%$ in the treatment of $3000 \mu \mathrm{g} / \mathrm{ml}$. The effect of purple sweet potato in suppressing inflammatory factors can be seen by decreasing COX-2 expression to $20.1 \%$ and IL-6 to $55 \%$ in the treatment of $3000 \mu \mathrm{g} / \mathrm{ml}$ extract. In addition, there was a decrease in the expression of haptoglobins and MCP-1 for all treatments. ${ }^{17}$

Zhuang et al. observed that administration of purple sweet potato treatment in mice could effectively reduce weight and adipose cells with a significance of $\mathrm{P}<0.001$. After 20 weeks of therapy, the reduced BDNF concentration due to obesity can be restored by the treatment of purple sweet potato with a significance of $\mathrm{P}<0.001$.

\section{CONCLUSION}

Pediatric obesity is a metabolic disorder happened to the children. Obesity handling program and anti-obesity medicine is not effective yet to manage this problem. ASN on the purple sweet potato can decrease the obesity through the mechanism in the GI system, adipose cell, and brain. ASN that is encapsulated by liposome in the form of pectin-based dry jelly has a potential as anti-obesity modality with the minimal side effects. The consumption is done orally by $24 \mathrm{mg} / \mathrm{kg}$ after eating.

\section{CONFLICT OF INTEREST}

There is no competing interest regarding manuscript

\section{FUNDING}

None 


\section{AUTHOR CONTRIBUTION}

All of author are equally contributed to the study from the conceptual framework, literature search strategy, data gathering, until synthesis the results in a narrative form.

\section{REFERENCES}

1. Xu S, Xue Y. Pediatric obesity: causes, symptoms, prevention and treatment. Exp Ther Med. 2016;11(1):15-20.

2. Badan Penelitian dan Pengembangan Kesehatan KKRI. Laporan hasil riset kesehatan dasar (riskesdas) Indonesia tahun 2013. Jakarta: CV Kiat Nusa; 2014:1-306.

3. World Health Organization. Prevalence of overweight and obesity in children and adolescents. 2009 [Accessed January 15, 2019]. [Available at: www.euro.who.int/ ENHIS].

4. WHO. Prioritizing areas for action in the field of population-based prevention of childhood obesity. Geneva: WHO; 2012 [Accessed January 15, 2019]. [Available at: http://www.who.int/about/licensing/].

5. Nevill AM, Bryant E, Wilkinson K, Gomes TN, Chaves R, Pereira $S$, et al. Can waist circumference provide a new "third" dimension to BMI when predicting percentage body fat in children? Insights using allometric modelling. Pediatr Obes. 2018;14(4):e12491:1-8.

6. Simmonds M, Llewellyn A, Owen CG, Woolacott N. Predicting adult obesity from childhood obesity: a systematic review and meta-analysis. Obes Rev. 2016;17(2):95-107.

7. Aktar N, Qureshi NK, Ferdous HS. Obesity: a review of pathogenesis and management strategies in adult. Delta Med Coll J. 2017;5(1):35-48.

8. Handayani O, Rahayu T, Budiono I, Fauzi L, Siyam N, Macdonald N, et al. Health promotion models to reduce childhood obesity in elementary school: a comparison study between Indonesia and Australia. J Sci Res Reports. 2015;7(1):1-10.

9. Lagerros YT, Rössner S. Obesity management: what brings success? Therap Adv Gastroenterol. 2013;6(1):77-88.

10. Staiano AE, Gonugunta N, Drazba KT. Childhood obesity treatment. Pennington Biomedical Research Centre; 2014. [Accessed January 15, 2019]. [Available at: https://www. pbrc.edu/obesitytoolkit/pdf/files/assets/common/downloads/files/ChildhoodObesityTreatment_web.pdf]

11. Mennella JA, Roberts K, Mathew PS, Reed DR. Children's perceptions about medicines: individual differences and tastes. BMC Pediatr. 2015;15:130.

12. Martin C, Li J. Medicine is not health care, food is health care: plant metabolic engineering, diet and human health. New Phytol. 2017;216(3):699-719.

13. Tensiska T, Marta H, Cahyana Y, Amirah NS. Application of encapsulated anthocyanin pigments from purple sweet potato (Ipomoea batatas L.) in jelly drink. KnE Life Sci. 2017;2:482-493

14. Badan Pusat Statistik. Produksi Ubi Jalar Menurut Provinsi (ton), 1993-2015. 2015. [Accessed January 15, 2019]. [Available at: https://www.bps.go.id/dynamictable/2015/09/09/883/produksi-ubi-jalar-menurut-provinsi-ton-1993-2015.html]

15. Esatbeyoglu T, Rodríguez-Werner $M$, Schlösser A, Winterhalter P, Rimbach G. Fractionation, enzyme inhibitory and cellular antioxidant activity of bioactives from purple sweet potato (Ipomoea batatas). Food Chem. 2017;221:447-456.

16. Ramdath DD, Padhi E, Hawke A, Sivaramalingam T, Tsao R. The glycemic index of pigmented potatoes is related to their polyphenol content. Food Funct. 2014;5(5):909-15.

17. Ju J-H, Yoon H-S, Park H-J, Kim M-Y, Shin H-K, Park K-Y, et al. Anti-obesity and antioxidative effects of purple sweet potato extract in 3T3-L1 adipocytes in vitro. J Med Food. 2011;14(10):1097-106.
18. Freemark M. Pediatric obesity: etiology, pathogenesis and treatment. 2nd edition. Switzerland: Springer Nature; 2018. h. 1-793.

19. Zhuang J, Lu J, Wang X, Hu W, Hong F, Zhao X, et al. Purple sweet potato color protects against high-fat diet-induced cognitive deficits through AMPK-mediated autophagy in mouse hippocampus. J Nutr Biochem. 2019;65:35-45.

20. Mignet N, Seguin J, Chabot GG. Bioavailability of Polyphenol Liposomes: A Challenge Ahead. Pharmaceutics. 2013;5(3):457-71.

21. Kakino Y, Hishikawa Y, Onodera R, Tahara K, Takeuchi H. Gelation factors of pectin for development of a powder form of gel, dry jelly, as a novel dosage form. Chem Pharm Bull (Tokyo). 2017;65(11):1035-1044.

22. Khoo HE, Azlan A, Tang ST, Lim SM. Anthocyanidins and anthocyanins: colored pigments as food, pharmaceutical ingredients, and the potential health benefits. Food Nutr Res. 2017;61(1):1361779.

23. Cheeseman MA. Artificial food color additives and child behavior. Environ Health Perspect. 2012;120(1):A15-6.

24. Maffeis C, Surano MG, Cordioli S, Gasperotti S, Corradi M, Pinelli L. A high-fat vs. A moderate-fat meal in obese boys: nutrient balance, appetite, and gastrointestinal hormone changes. Obesity (Silver Spring). 2010;18(3):449-455.

25. Batterham RL, Cohen MA, Ellis SM, Le Roux CW, Withers DJ, Frost GS, et al. Inhibition of food intake in obese subjects by peptide YY3-36. N Engl J Med. 2003;349(10):941-948.

26. Mittelman SD, Klier K, Braun S, Azen C, Geffner ME, Buchanan TA. Obese adolescents show impaired meal responses of the appetite-regulating hormones ghrelin and PYY. Obesity (Silver Spring). 2010;18(5):918-925.

27. Mojbafan M, Afsartala Z, Amoli MM, Mahmoudi M, Yaghmaei P, Larijani B, et al. Liver alpha-amylase gene expression as an early obesity biomarker. Pharmacol Rep. 2017;69(2):229-34.

28. Adamska E, Ostrowska L, Górska M, Krętowski A. The role of gastrointestinal hormones in the pathogenesis of obesity and type 2 diabetes. Gastroenterol Rev. 2014;9(2):69-76.

29. Kojima M, Hosoda H, Date $Y$, Nakazato M, Matsuo $H$, Kangawa K. Ghrelin is a growth-hormone-releasing acylated peptide from stomach. Nature. 1999;402(6762):656-660.

30. Adrian TE, Ferri GL, Bacarese-Hamilton AJ, Fuessl HS, Polak JM, Bloom SR. Human distribution and release of a putative new gut hormone, peptide YY. Gastroenterology. 1985;89(5):1070-1077.

31. Gautier JF, Choukem S-P, Girard J. Physiology of incretins (GIP and GLP-1) and abnormalities in type 2 diabetes. Diabetes Metab. 2008;34 Suppl 2:S65-72.

32. Klöting N, Blüher M. Adipocyte dysfunction, inflammation and metabolic syndrome. Rev Endocr Metab Disord. 2014;15(4):277-287.

33. Amano SU, Cohen JL, Vangala P, Tencerova M, Nicoloro SM, Yawe JC, et al. Local proliferation of macrophages contributes to obesity-associated adipose tissue inflammation. Cell Metab. 2014;19(1):162-171.

34. Lumeng CN, Bodzin JL, Saltiel AR. Obesity induces a phenotypic switch in adipose tissue macrophage polarization. J Clin Invest. 2007;117(1):175-184.

35. Weisberg SP, McCann D, Desai M, Rosenbaum M, Leibel RL, Ferrante AW. Obesity is associated with macrophage accumulation in adipose tissue. J Clin Invest. 2003;112(12):1796-1808

36. Shi H, Kokoeva MV, Inouye K, Tzameli I, Yin H, Flier JS. TLR4 links innate immunity and fatty acid-induced insulin resistance. J Clin Invest. 2006;116(11):3015-3025.

37. Rutkowski JM, Stern JH, Scherer PE. The cell biology of fat expansion. J Cell Biol. 2015;208(5):501-512.

38. Saponaro C, Gaggini M, Carli F, Gastaldelli A. The subtle balance between lipolysis and lipogenesis: a critical point in metabolic homeostasis. Nutrients. 2015;7(11):9453-9474.

39. Dentin R, Pégorier JP, Benhamed F, Foufelle F, Ferre P, Fauveau V, et al. Hepatic glucokinase is required for the synergistic action of chrebp and srebp-1c on glycolytic and lipogenic gene expression. J Biol Chem. 2004;279(19):20314-20326. 
40. Haliloglu B, Bereket A. Hypothalamic obesity in children: pathophysiology to clinical management. J Pediatr Endocrinol Metab. 2015;28(5-6):503-513.

41. Wardlaw SL. Hypothalamic proopiomelanocortin processing and the regulation of energy balance. Eur J Pharmacol. 2011;660(1):213-219.

42. Bray GA, Inoue S, Nishizawa Y. Hypothalamic obesity. The autonomic hypothesis and the lateral hypothalamus. Diabetologia. 1981;20 Suppl:366-377.

43. Wicaksono LA, Widyaningsih TD, Yunianta. Anthocyanin extraction from purple sweet potato cultivar antin-3 (Ipomoea batatas L.) using maceration, microwave assisted extraction, ultrasonic assisted extraction and their application as anti-hyperglycemic agents in alloxan-induced wistar rats. International Journal of PharmTech Research. 2016;9(3):181-92.

44. Jufri M. Arah dan perkembangan liposome drugs delivery systems. Majalah Ilmu Kefarmasian. 2004;1(2):59-68.

45. Zhao L, Temelli F, Chen L. Encapsulation of anthocyanin in liposomes using supercritical carbon dioxide: Effects of anthocyanin and sterol concentrations. J Funct Foods. 2017;34:159-167.

46. Bryła A, Lewandowicz G, Juzwa W. Encapsulation of elderberry extract into phospholipid nanoparticles. J Food Eng. 2015;167(B):189-195.

47. Hwang JM, Kuo HC, Lin CT, Kao ES. Inhibitory effect of liposome-encapsulated anthocyanin on melanogenesis in human melanocytes. Pharm Biol. 2013;51(8):941-947.

48. de los Monteros LAGE, Robles Ramirez M del C, Mora R. Soybean and Obesity. In: Soybean - Biochemistry, Chemistry and Physiology. InTech; 2011.

49. Mourad AM, de Carvalho Pincinato E, Mazzola PG, Sabha M, Moriel P. Influence of soy lecithin administration on hypercholesterolemia. Cholesterol. 2010;2010:824813.

50. Toita R, Kawano T, Murata M, Kang JH. Anti-obesity and anti-inflammatory effects of macrophage-targeted interleukin-10-conjugated liposomes in obese mice. Biomaterials. 2016;110:81-88.

51. Schratter G, Karbiener M, Almer G, Mangge H, Scheideler M, Prassl R. Liposomes for microRNA delivery to human adipocytes. Atherosclerosis. 2016;252:e131.

52. Saffoon N, Uddin R, Huda HN, Sutradhar BK. Enhancement of Oral Bioavailability and Solid Dispersion: A Review. J Appl Pharm Sci. 2011;1(7):13-20.

53. Burin VM, Rossa PN, Ferreira-Lima NE, Hillmann MCR, Boirdignon-Luiz MT. Anthocyanins: optimisation of extraction from Cabernet Sauvignon grapes, microcapsulation and stability in soft drink. Int J Food Sci Technol. 2011;46(1):186-193.

54. Wu T, Jiang Z, Yin J, Long H, Zheng X. Anti-obesity effects of artificial planting blueberry (Vaccinium ashei) anthocyanin in high-fat diet-treated mice. Int J Food Sci Nutr. 2016;67(3):257-264

55. Hwang J-M, Kuo H-C, Lin C-T, Kao E-S. Inhibitory effect of liposome-encapsulated anthocyanin on melanogenesis in human melanocytes. Pharm Biol. 2013;51(8):941-947.

56. Fernandes I, de Freitas V, Reis C, Mateus N. A new approach on the gastric absorption of anthocyanins. Food Funct. 2012;3(5):508-16.

57. Matuschek MC, Hendriks WH, McGhie TK, Reynolds GW. The jejunum is the main site of absorption for anthocyanins in mice. J Nutr Biochem. 2006;17(1):31-36.

58. Pojer E, Mattivi F, Johnson D, Stockley CS. The case for anthocyanin consumption to promote human health: a review. Compr Rev Food Sci Food Saf. 2013;12(5):483-508.

59. Manach C, Williamson G, Morand C, Scalbert A, Rémésy C. Bioavailability and bioefficacy of polyphenols in humans. I. Review of 97 bioavailability studies. Am J Clin Nutr. 2005;81(1 Suppl):230S-242S.
60. Kay CD. Aspects of anthocyanin absorption, metabolism and pharmacokinetics in humans. Nutr Res Rev. 2006;19(1):137-46

61. Ziberna L, Tramer F, Moze S, Vrhovsek U, Mattivi F, Passamonti S. Transport and bioactivity of cyanidin 3-glucoside into the vascular endothelium. Free Radic Biol Med. 2012;52(9):1750-1759.

62. Vanzo A, Scholz M, Gasperotti M, Tramer F, Passamonti S, Vhrovsek U, et al. Metabonomic investigation of rat tissues following intravenous administration of cyanidin 3-glucoside at a physiologically relevant dose. Metabolomics. 2013:9(1):88-100.

63. Sakakibara H, Ogawa T, Koyanagi A, Kobayashi S, Goda T, Kumazawa S, et al. Distribution and excretion of bilberry anthocyanins in mice. J Agric Food Chem. 2009;57(1):7681-7686.

64. Passamonti S, Vrhovsek U, Vanzo A, Mattivi F. Fast access of some grape pigments to the brain. J Agric Food Chem. 2005;53(18):7029-7034.

65. Hribar U, Ulrih NP. The metabolism of anthocyanins. Curr Drug Metab. 2014;15(1):3-13.

66. Vanzo A, Terdoslavich M, Brandoni A, Torres AM, Vrhovsek U, Passamonti S. Uptake of grape anthocyanins into the rat kidney and the involvement of bilitranslocase. Mol Nutr Food Res. 2008;52(10):1106-1116.

67. Del Bò C, Ciappellano S, Klimis-Zacas D, Martini D, Gardana C, Riso P, et al. Anthocyanin absorption, metabolism, and distribution from a wild blueberry-enriched diet (Vaccinium angustifolium) is affected by diet duration in the Sprague-Dawley rat. J Agric Food Chem. 2010;58(4):2491-2497.

68. Kato M, Tani T, Terahara N, Tsuda T. The Anthocyanin Delphinidin 3-Rutinoside Stimulates Glucagon-Like Peptide-1 Secretion in Murine GLUTag Cell Line via the $\mathrm{Ca} 2+/$ Calmodulin-Dependent Kinase II Pathway. PLoS One. 2015;10(5):e0126157.

69. Badshah H, Ullah I, Kim SE, Kim T, Lee HY, Kim MO. Anthocyanins attenuate body weight gain via modulating neuropeptide $\mathrm{Y}$ and GABAB1 receptor in rats hypothalamus. Neuropeptides. 2013;47(5):347-353.

70. Jang HH, Kim HW, Kim SY, Kim SM, Kim JB, Lee YM. In vitro and in vivo hypoglycemic effects of cyanidin 3-caffeoyl-p-hydroxybenzoylsophoroside-5-glucoside, an anthocyanin isolated from purple-fleshed sweet potato. Food Chem. 2019;272:688-693.

71. Mundi MS, Karpyak M V, Koutsari C, Votruba SB, O’Brien PC, Jensen MD. Body fat distribution, adipocyte size, and metabolic characteristics of nondiabetic adults. J Clin Endocrinol Metab. 2010;95(1):67-73.

72. Talavéra S, Felgines C, Texier O, Besson C, Gil-Izquierdo A, Lamaison JL, et al. Anthocyanin metabolism in rats and their distribution to digestive area, kidney, and brain. J Agric Food Chem. 2005;53(10):3902-3908.

73. Maekawa F, Fujiwara K, Toriya M, et al. Brain-derived neurotrophic factor in $\mathrm{VMH}$ as the causal factor for and therapeutic tool to treat visceral adiposity and hyperleptinemia in type 2 diabetic Goto-Kakizaki rats. Front Synaptic Neurosci. 2013;5:7.

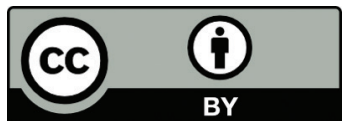

This work is licensed under a Creative Commons Attribution 